\title{
Harmonizing the Educational Globe. World Polity, Cultural Features, and the Challenges to Educational Research
}

\author{
Daniel Tröhler
}

(C) Springer Science+Business Media B.V. 2009

\begin{abstract}
The general thesis of this paper is that the motives of the currently dominant global educational governance are rooted in a specific cultural milieu in the time of the Cold War, more precisely in the late 1950s, heading to a harmonious world. The more specific thesis is that a series of failures in the achievement of this harmonized globe led to reforms in educational governance, leading eventually to the development of instruments like large-scale assessments, such as PISA. The concluding thesis of the paper is that precisely because the idea of global governance is rooted in a specific culture, its instruments run the risk of only affecting formal structures of education in other cultures rather the inner activities of the 'educational fabric'.
\end{abstract}

Keywords Educational governance $\cdot$ Globalization · Neo-institutionalism ·

Cold war · Sputnik · OECD · PISA · Democracy · Expertocracy · Educational research

In the past two or three decades we have been witnessing an ongoing worldwide assimilation of the different national educational systems. This process has been promoted by international organizations such as the World Bank or the International Monetary Fund investing millions of dollars in the school systems of poorer countries on the condition that organizational structures and governance systems that proved to be successful in the rich countries are implemented. The effects of this global governance are quite tangible. Sociologists describe this process as "world institutionalization of education" (Meyer and Ramirez 2000) with standardized ideas about organizational structures, compulsory schooling, curricula, and professionally trained teachers resulting in an educational "world polity" (Meyer et al. 1994).

These developments have evoked criticism. Some critics depict educational policy makers as being string puppets of the global economy and reducing students to measurable

This article was presented as an inauguration lecture at the University of Luxembourg, Campus Limpertsberg, February 17, 2009. I thank Tom Popkewitz and Gert Biesta for their helpful comments.

D. Tröhler $(\bowtie)$

University of Luxembourg, FLSHASE, Campus Walferdange, Luxembourg City, Luxembourg e-mail: daniel.troehler@uni.lu 
results. Other critics have argued that in any case the global dissemination of ideals, goals, and means is limited only to formal structures - in other words to polity issues - and hardly affect the inner activities of education, such as for example classroom instruction (Meyer and Rowan 1977, 1978, 2000). The same critics have also pointed to the fact that this form of globalization is to be understood as a spread of western ideas rather than a global consensus between equal partners-ideas that were successful only because they were promoted by the money provided by the different governmental and non-governmental organizations and new international educational bureaucracies like UNESCO or UNICEF (Chabbott 2003).

What is being criticized here on a global scale can well be applied to the west itself. The western systems are by no means harmonized, but they, too, are on the way. It is sufficient to mention the Bologna Process, aiming at the creation of a harmonized European Higher Education Area by 2010, and similar attempts on lower school levels in single countries with decentralized structures. ${ }^{1}$ Whereas on a global scale the World Bank and other international organizations are the promoters of world polity, for the western sphere it is the International Association for Educational Assessment (IAEA) and, most of all, the Organization for Economic Co-operation and Development, the OECD, particularly with its comparative testing instrument, the Program for International Student Assessment, known as PISA.

I am interested in this process of harmonization and its assumed limitations to formal structures of education and, conversely, in its weak capability to have the effects that it is aiming for: namely, to improve formal education, respectively enhance school quality. Within the limits of this paper, I will narrow my scope to the western world only and to its most distinguished instrument, PISA. My general thesis is that the motives of the new global educational governance are rooted in a specific cultural milieu in the time of the Cold War, more precisely in the late 1950s, heading to a harmonious world. My more specific thesis is that a series of failures in the achievement of this harmonized globe led to reforms in educational governance, leading eventually to the development of instruments like large-scale assessments, such as PISA. And my concluding thesis is that precisely because the idea of global governance is rooted in a specific culture, its instruments run the risk of only affecting formal structures of education in other cultures rather the inner activities of the 'educational fabric.' I will develop my theses in five steps. First, I will analyze some characteristics of PISA as prominent tokens in the harmonizing of the educational globe. Then I will focus on the emergence of these characteristics in the context of the 1950s and its vision of global development. In the third step I will reconstruct how the shock of Sputnik led to educationalization of this global vision and focus on the major agency of this concept, the OECD. In the fourth step I will illustrate how the failure of the educational initiatives led to a new governance model in which standardized large-scale testing emerged as the chief instrument in educational governance. I will close my paper by asking what challenges await educational research in the face of these global-political developments defining research primarily as supplier of needed policy information.

\footnotetext{
${ }^{1}$ Countries with de-centralized educational policies like Germany or Switzerland are trying to harmonize primary education through specific institutions such as the Conference of the German Cultural Ministers (Kultusministerkonferenz) and the Swiss Conference of Cantonal Ministers of Education (Schweizerische Konferenz der Kantonalen Erziehungsdirektoren).
} 


\section{PISA and the Harmonization of the Educational Globe}

PISA's basic concern is to measure how well 15 year-old adults are prepared to meet the "challenges of today's knowledge society" (OECD 2001, p. 14). However, what these "challenges" are and what "today's knowledge society" means are not defined. The reader learns that these assumed challenges could be mastered successfully with specific competencies. Since only competencies in science, mathematics and language are tested, one has to assume that competencies in these areas are crucial to coping with the unidentified challenges.

Besides the distinction between allegedly important and allegedly less important competencies, PISA makes a distinction between useful and useless knowledge. There is knowledge that is "merely learned," and there is learned knowledge than can be used in the future life of the students (OECD 2001, p. 14). Again, the distinction is not elucidated, but it is nevertheless crucial. Because PISA wants to look at "young people's ability to use their knowledge and skills in order to meet real-life-situations," the focus is not directed at what students learn in school on the basis of their curriculum and textbooks (p. 16). PISA pretends to know what young people need to master their lives in the future, but at the same time it neglects the question of how students master their lives in their very own presentnamely, as learning students at school. "Assessments that test only mastery of the school curriculum can offer a measure of the internal efficiency of school systems. They do not reveal how effectively schools prepare students for life after they have completed their formal education" (p. 27).

As an empirical research design PISA knows that it cannot disregard student experiences, even though it disregards the concrete context of these experiences: the real school, its curriculum, its textbooks, etc. In an odd construction PISA offers the following solution out of this problem: "PISA offers a new approach to considering school outcomes, using as its evidence base the experiences of students across the world rather than in the specific cultural context of a single country" (p. 27). However, the disregard of the national curriculum, organization, and textbooks does not stop PISA from thinking of its results as being essential to the particular national educational policies. Without these results, PISA says, parents, taxpayers, and politicians "lack a means of judging the comparative effectiveness of their educational systems" (p. 18).

Comparisons are always and as a matter of principle normative. "Normative" means that facts are being related to an ideal standard or model. "Comparative" means that different facts are related to the same ideal standard or model—philosophers talk about the tertium comparitionis as the basic principle of comparison. Regarding achievements, different variables such as the curriculum, the textbooks, the actual lessons, and the quality of the teachers could be considered, and of course it is only fair to account for the family background of the students, too. All these variables composing the tertium comparitionis of the comparison are fundamentally empirical, but PISA does not consider them in its comparison of achievement. It is only after the results have been engendered, after the comparison of cognitive achievement, that PISA turns its interest to some of the empirical questions such as family background, gender, or school structures. The question is where this tertium comparitionis originates and how it gained such a broad legitimacy, rightly or not. As I mentioned in the introduction, my general thesis is that its origins can be found in the Cold War ideology of the 1950s. 


\section{The Vision of “One World," the Experts, and the Ideology of Development}

After the Second World War, few Americans doubted the supremacy of their nation leading the world to enduring peace and welfare. In this context the notion of "One World" became popular. It had been used as early as 1943 by the presidential candidate Wendell Lewis Willkie, and it indicated the idea of a safe and united world based on the security and well-being of common people throughout the world, provided by U.S. world leadership (Fousek 2000, p. 79). Annoyingly, one of the former allies, the Soviet Union, had expressed similar ambitions on its own agenda and had thus become more and more a distracting factor on the global vision of "One World" under the leadership of the United States.

In order to tackle the Soviets' agenda, leading intellectuals in the United States constructed an important distinction. The communist ambitions of a united and just world of equal citizens were labeled "ideological," while the western self-perception was deemed to be free of ideology. In this context the phrase "the end of ideology" became a popular slogan to rally intellectuals worldwide against the Soviet Union's postwar ideological offense (Gilman 2003, p. 58). This very same idea returned in 1989 , by the way, when Francis Fukuyama proclaimed the "end of history" after the fall of the Iron Curtain.

The self-ascription to be free of ideology was deduced from the self-assessment of being the most developed country in the world. Looking at its own history, there was little doubt that the United States had solved the major problems of modern societies by far the best. But its self-asserted American exceptionalism did not prevent the rise of the idea that same time its unique example was universal and exemplary, too. In other words, the United States were both unique and a model for others; it had something to offer the world by its very example (Gilman 2003, p. 63). An expression of this "American nationalist globalism" (Fousek 2000) can be seen as early as in 1947 in the former vice-president of the United States, Henry A. Wallace, saying: "By reason of history, geography and sheer economic strength America has it in her grasp to furnish that great and last peace which the prophets and sages have preached for thousands of years" (quoted in Fousek 2000, p. 11). The religious language of salvation is not misleading but rather characteristic, as Denis Brogan, a British commentator of the United States, noticed in 1957: "The notion of 'mission' is far wider than it was; the whole world is the parish of the United States as a government and a culture" (quoted in Gilman 2003, p. 69).

The globalization of the American self-perception as world model free of ideology has served in many international organizations as an indubitable benchmark, precisely because it proclaimed to be universal. The key word of this millennium project was development. This notion allowed the division of the world in three parts: first the developed countries, thus the United States and to a lesser degree Western Europe, then the wrongly developed countries, thus the communist, and last the former colonies as underdeveloped countries in south-eastern Europe, Asia, Africa, and South America. Whereas there was little hope to convince the communist leaders in the Soviet Union or in China of the dignity of the western idea of the end of ideology, American leaders began to get more and more involved in developing underdeveloped countries. The fact that the Soviet Union had the same strategy for their vision of the end of class society caused the manifold problems called the Cold War, with many proxy wars around the globe.

The project of developing underdeveloped countries was targeted at establishing an industrial democracy based on the model of the United States. American experts advised local authorities, if necessary in military affairs in order to prevent communist agitation-not 
always successful if we think of the Vietnam tragedy. ${ }^{2}$ The concept of the expert as a key actor for development in both domestic and foreign affairs challenged the democratic tradition of the United States that was traditionally characterized as grass-rooted. The attractiveness of the expert as a leading figure originated from the perception of an increasing complex world and the decreasing faith in popular regimes; Nazi Germany and the Soviet Union were seen as possible degenerations of too popular governments that had to be bent forward. In this altered understanding, democracy works essentially as a form of competition among elites for votes, and therefore democracy is reduced to its procedural function of election. Not even high voter participation in elections is been sought after, far from it: "That democracy is best, in which people participate least" was the general assumption of the expertise-driven democracy in the 1950s (quoted in Gilman 2003, p. 48).

The idea of the expert goes along with the idea that major problems can be solved by scientific means, technology, and rational planning. The impressive development in both science and technology had been perceived as the result of a free people and thus as a core part of the American world mission. ${ }^{3}$ Therefore, technology was not merely a technical means but a visible token of the universal process towards "One World." The atomic bomb that helped to end the war in Japan was no more than the dot on the 'i' of the technological sublime in the self-perception of the Americans (Nye 1994). As early as in 1949, President Harry S. Truman said: “The United States is preeminent among nations in the development of industrial and scientific techniques. The material resources which we can afford to use for the assistance of other peoples are limited. But our imponderable resources in technical knowledge are constantly growing and are inexhaustible. (...) Greater production is the key to prosperity and peace. And the key to greater production is a wider and more vigorous application of modern scientific and technological knowledge" (quoted in Gilman 2003, p. 71). Everything seemed to be basically in order, despite the Korean conflict, the Hungarian revolt, and the darkening situation in Vietnam-that is, until a 23-inch metal ball called Sputnik was launched by the Soviet Union on October 4, 1957. It was the first human-made object to orbit the earth, and it symbolized the superiority of communist technology. The cultural shock of Sputnik effected several immediate reactions. One was the founding of the National Aeronautics and Space Administration NASA in 1958, and another was the passage of the National Defense Education Act, or NDEA, by the U.S. Congress the same year.

\section{Sputnik and the Educationalization of Development: NDEA and OECD}

The rational for the NDEA was as follows: "The Congress hereby finds and declares that the security of the Nation requires the fullest development of the mental resources and technical skills of its young men and women" (NDEA 1958, Sec. 101). As the "defense of this Nation depends upon the mastery of modern techniques developed from complex scientific principles," the Congress argued, more young people should be educated in three core subjects, namely in "science, mathematics and modern foreign languages and trained

\footnotetext{
2 "After the Korean War, the U.S. foreign economic aid program would become inseparable from military concerns" (Gilman 2003, p. 44).

3 Not everywhere has this mission enjoyed undivided appreciation, not even in the western world. The French journalist Jean-Jacques Servan-Schreiber attracted high attention in 1967 with the publication of his book Le Défi Américain (The American Challenge 1967), accusing the United States of colonizing Europe by the technological advances. It was translated in 15 different languages and sold almost one million copies.
} 
in technology" (ibid.). Through the lenses of PISA this selection looks quite normal, for the only difference is that NDEA fosters foreign languages rather than the native language. However, it is worthwhile to remember that in the eighteenth century, for instance, two of those three subjects would not even be a part of the compulsory curriculum of the schoolnamely, mathematics and science. By contrast, the most important subjects in mass schooling of early modern times, the Catechism and religious songs, have disappeared in this selection in the same way that history has disappeared, that important subject in primary and secondary education in the nineteenth and twentieth centuries. In other words, what looks normal through the lenses of PISA only appears to us to be normal because the Cold War educational policy is the very ground and origin of PISA.

The NDEA was a novelty insofar as for the first time in U.S. history the federal government was interfering in educational affairs regarding specific curricular contents (Sufrin 1963, p. 3). NDEA did not just want to support the local and state authorities to educate students generally; instead, it connected financial aid to promotion of mathematics, science, and foreign languages. This interference is a reflection of the above-mentioned shift towards elite democracy and faith in experts. Until the NDEA, formal education issues had been exclusively in the hands of state, district, and local school boards, who were elected by popular vote. But in their attempt to change education in order to combat the national threat by the Soviets, the Federal experts obviously challenged this local model of democratic control. The instrument of this governmental interference was called "incentive," a notion that has since made a career in educational policy as another notion that described the legitimation of this interference, namely "excellence": "The NDEA emphasizes the pursuit of excellence for the individual as the prime defense measure in democracy" (Sufrin 1963, p. 16), as one of the defenders of NDEA said. The original twoparty ideology, development, and "One World" had become a three-party conceptnamely education, development, and "One World." And it is this very model that was adopted by the Organization for Economic Co-operation and Development, OECD, and spread all over the globe.

The OECD was founded in same year that the NDEA program for financial aid to the applying schools started, in 1960. Its precursor organization had been the Organization for European Economic Co-operation (OEEC), founded on April 16, 1948, emerging from the Marshall Plan for rebuilding and creating a stronger foundation for the countries of Western Europe, and repelling — according to the Truman's Doctrine ${ }^{4}$ - communism after World War II. Its first meeting was held in 1961 in Washington, D.C. The new strategy of the old endeavor to develop the "One World" can be detected in the title of the conference: Policy Conference on Economic Growth and Investment in Education. Unmistakably, the political motive behind the conference was the Soviet Union (OECD 1961, pp. 5, 18, 21); the key to success was economic growth. Because education was thought to be a "key to more rapid and more meaningful economic growth" in the "age of science" (pp. 19, 21), failing education would cause a stammering economy and make the project of "One

\footnotetext{
${ }^{4}$ President Harry Truman held his Special Message to the Congress on Greece and Turkey-which eventually became the so-called Truman Doctrine-on March 12, 1947. In this message he asked the Congress for immediate financial aid for both Turkey and Greece, which were being threatened by communist rebels. "The seeds of totalitarian regimes are nurtured by misery and want. They spread and grow in the evil soil of poverty and strife. They reach their full growth when the hope of a people for a better life has died. We must keep that hope alive. The free peoples of the world look to us for support in maintaining their freedoms. If we falter in our leadership, we may endanger the peace of the world-and we shall surely endanger the welfare of this Nation." Truman was successful and was able to convince the Congress: Both countries received several hundred millions of dollars from the U.S. government in 1947 (Truman 1947).
} 
World" impossible. ${ }^{5}$ However, the scope remained the whole world, not just the countries of OECD. In the eyes of the actors, the "more advanced" countries owed help to the "underdeveloped areas to assess their present and long-term needs for education in relation to economic and other development objectives" (p. 14).

A developing economy was still seen as the main engine towards the harmonization of the globe, but - to stick to the metaphor-with the Sputnik shock, it was realized that the engine needed fuel, and the fuel was educated people. In other words and briefly stated, the great western project of harmonizing the world was educationalized. However, the actors of this shift were by no means educationalists, quite on the contrary. As one of the key speakers at the conference said, "May I say that, in this context, the fight for education is too important to be left solely to the educators" (OECD 1961, p. 35). Accordingly, the conference had brought together "those with policy responsibilities for education and national budgets as well as professional economists and experts" (p. 9). Of the four keynote speakers one was a lawyer (Dean Rusk, U.S. Secretary of State), the second had received his university degree in political and social sciences (Thorkill Kristensen, Secretary-General of the OECD), and the third and the fourth were economists by training (Philipp Coombs, U.S. Assistant Secretary of State for Educational and Cultural Affairs, and Walter H. Heller, Council of Economic Advisers to the President of the United States).

Accordingly, the major theory that the members at the OECD conference were referring to was not primarily an educational but an economic theory: human capital theory. Human capital theory had been developed right in the wake of the Sputnik consternation and had become highly attractive very quickly. The general postulate of human capital theory is that education should be seen not primarily as expenditure but as investment with the perspective of benefit. In other words, education has to be seen as investment in human beings. "It is only very recent," Theodore Schultz said in 1962, "that studies of human investment have been undertaken. These studies all enter upon empirical research, in particular to a separation of acquired from inherited capabilities" in relation to "economic growth, structure of wages and salaries, and the distribution of personal income" (Schultz 1962, p. 8). Human capital theory is not restricted to the last of these three points, for it has an overall scope: "Schooling benefits many persons other than the student. It benefits the student's future children, who will receive informal education in the home; and it benefits neighbors, who may be affected favorably by the social values developed in children by the schools and even by the quietness of the neighborhood while the schools are in session" (Weisbrod 1962, p. 197). The scope is still the one of earthly redemption to be achieved with a major reform in perceiving the potentials of education: "Schools may be viewed as firms that specialize in 'producing' schooling. The educational establishment, which includes all schools, may be viewed as an industry" (Schultz 1963, p. 4).

\section{The Reorganization of the Educationalization of Development: Output Steering}

The 1961 recipe of both the NDEA and the OECD was what we call today "input steering." Education as investment meant improving teacher education, upgrading the

\footnotetext{
5 It was made clear that governments needed to invest more money in education in order to enforce both "a new level of culture and human dignity" as essentials of a democracy and the advancement of science and technology, because the "economic progress is itself increasingly dependent on the development of education and on scientific research" (p. 5f., see pp. 9ff, 19, 21).
} 
curriculum and the textbooks in specific eras, and developing learning techniques and "learning machines" (OECD 1961, pp. 11f, 25). They decided that much more data from the individual countries were needed in order to plan in detail educational innovation for economical development. The "first importance for sound educational planning and for the development of education programmes" was to collect "excellent statistical data in respect of pupils, teachers, buildings and finance" in an "international comparable way" (OECD 1961, p. 13). ${ }^{6}$ The general concept was quantitative, not qualitative (ibid., p. 10).

Both characteristics of the major concept of securing development by enhanced education, its input and its quantitative orientation, were reversed about 25 years later. The turnaround to quality control and output steering was preceded by a new, costly, and unsuccessful American campaign for better education after 1980. This campaign had been triggered by traumatic events in the late 1960s and 1970s-the OPEC oil embargo, the stock market crash, the Vietnam War disaster, the Watergate scandal, the Civil Rights Movements and riots, the successful Japanese and then the Korean car industry, and Ayatollah Khomeini's forming of the explicitly anti-modern Islamic Republic of Iran. Again, the anti-Soviet stimulus was used, when a professor of mathematics (Wirszup 1981) complained in 1981 about "The Soviet Challenge. The new mathematics curriculum required of all students in the U.S.S.R. is superior to that of any other country" and stated that the "recent Soviet educational mobilization ... poses a formidable challenge to the national security of the United States" (p. 360). Based on meanwhile available comparative international data provided by international organizations, further scholars witnessed a "striking and highly significant ... decline in mean scores" in "cognitive achievements" (Lerner 1982, pp. 67, 69f). There was a sobering recognition that higher spending on education on the input side of schooling did not necessarily affect the quality of achievement on the output side of education (p. 72). ${ }^{7}$ Two major reports in 1983 testified to the ultimate need for educational reform using the catchword "excellence." One of the reports was the famous federal government report, "A Nation at Risk," by the National Commission on Excellence in Education (National Commission 1983), and the other was the Education Commission of the States' report, "Action for Excellence: A Comprehensive Plan to Improve Our Nation's Schools" (Task Force 1983). Both reports started by assessing an economic decline of U.S. industry as compared to other national industries and then connected the economic slide to the decline of education. ${ }^{8}$ The success of the reports was impressive; a broad campaign for improving education was on its way, with millions of dollars to be invested. However, the efforts failed to a large degree, and the hopes placed in education were being disappointed once more.

What happened around the time of the end of the Cold War is intriguing and decisive for today's educational policy in the world. The poor results of the reform attempts did not lead the experts to reexamine their basic hopes and assumptions about the school and

\footnotetext{
6 And indeed, in the 1960s and 1970s the experts published national reports on the progress of educational policy (for a summary of the first reports, see OECD 1979).

7 Accordingly, they looked for other variables, which were then summed up in one: "the hard work variable" (Lerner 1982, p. 72), a value that represented the conservative Reagan era best.

8 "In the seventies, productivity in manufacturing industries grew nearly four times as fast in Japan, and twice as fast in West Germany and France, as in the United States" (Task Force 1983, p. 13). "We live among determined, well-educated, and strongly motivated competitors. We compete with them for international standing and markets, not only with products but also with the ideas of our laboratories and neighborhood workshops. America's position in the world may once have been reasonably secure with only a few exceptionally well-trained men and women. It is no longer" (National Commission 1983, p. 6).
} 
education. Instead, they sought new strategies to improve the quality of education by enhancing the influence of the experts. In contrast to the decades before, the strategies were not headed towards improving the input-that is to say, improving teaching quality, curriculum, or textbooks - but instead aimed at changing the governance structure of the school in order to improve the quality. In the eyes of the experts, it was actually the locally elected school boards that were the culprits in the failing reforms and not the reform concepts themselves.

The accusation that the local school boards were the major cause of failing reforms signified a dramatic clash between the idea of an elite democracy and the local democracy, or between expertise and common sense. The experts did not vacillate, and they declared the local school boards to be "living fossils of an earlier age" (Finn 1991, p. 32). The influence of those fossils should be restricted in order to reach a new balance between state government with its experts and the individual school in order to push through the reform programs by means of incentives. Therefore, more focus should be placed on output (testing results) than on input, as previously. The state governments would then serve as monitoring agencies and in this way ensure that state guidelines are met. ${ }^{9}$ Accordingly, David Conley, director of the Center for Educational Policy Research, states that the school boards will serve the state government and its experts rather than the local schools by helping the former to increase the accountability of the individual schools, and if they fail to do so, they should be passed over by the state (Conley 2003, p. 146). It is this expert ideology and its strategy of bypassing the local authorities by isolating the single schools in order to make them accountable to the central authorities that is in the background of the PISA program, neglecting real contexts of schooling. The euphemist notion of that process is called the autonomy of the single schools. ${ }^{10}$

This ideology of reducing local democracy and increasing central experts on the one hand, and governing by financial incentives to motivate the single schools for better achievement on the other, became the major ideology for the No Child Left Behind Act signed by George W. Bush in 2001. The Act obligated schools to achieve minimum standards in three tested subjects, mathematics, science, and language. ${ }^{11}$ The very same outline was used by the OECD. In contrast to the federal government of the United States, the incentive of OECD is not monetary but instead draws on national(istic) passions, as we may detect for instance in Germany's reaction: "The aim is clear: 10 years from now Germany has to belong to the five leading educational countries. That is why our school system has to bring our children and adolescents to higher education, to higher proficiency level, and social competencies. That is exactly what happens in Finland and Canada. These countries have to be our measuring stick" (Bildungsministerium 2003, cited in Oelkers 2004, p. 33).

\footnotetext{
9 This move correlates with the rise of the neo-classical theories in economics, superseding Keynesianism and the idea of the welfare state in the 1980s. The "swearword" of this school is "neo-liberalism" (see Hartwich 2009). However, the persuasiveness of this ideology weakened considerably in the economic crisis of 2008/2009, when the national governments in the world had to support private banks with billions of dollars paid by taxpayers.

${ }^{10}$ For a discussion about how this shift towards the single school can conflict with the idea of democracy see Biesta 2004.

11 With the little Post-Cold War specification that the science results are not counted (see Garmoran 2007).
} 


\section{Schooling, the Culture of Testing, and the Role of Educational Research}

The autonomy of the single schools to achieve minimum standards in a few selected fields defined by experts has become the global model of school reform. ${ }^{12}$ The unconsidered recognition of this American policy shift from input steering to output steering by OECD and European experts raises some questions, for it is by no means the only solution. It might be unique, but it is by no means a universal model. It is a result of the millennial ambitions in the Cold War that became educationalized in the early 1960s in a context in which the federal government had no direct instrument for intervening in educational affairs at all. To a European it is inconceivable that an American president, as the most powerful man in the world, could not be able to direct any school between Maine and California to use a specific textbook in the classroom or to increase the weekly school hours even by $10 \mathrm{~min}$. In other words: The American model of expert-driven standardized assessment of autonomous schools, with an equivalent incentive system, only makes sense where central experts feel the need to undermine locally elected authorities. Hence, this model is as culturally encoded as any other. It is a result of a particular historical process in a specific cultural setting. That the agents of this model claim it to be universal, and free of concrete circumstances and ideologies, does not help the matter. Rather, it is no more than the expression of this very cultural ideology.

It is not incomprehensible that many policy makers in Europe were attracted by this ideology, sponsored corresponding research projects, and drew pertinent conclusions contributing to the educational world polity. Quickly they enlarged the administration departments of education with the addition of experts. In Zurich, for example, in the 30 years between 1973 and 2003 the number of the staff was quadrupled (Tröhler 2008). However, the policy makers often forgot that in contrast to the United States, they do have relevant steering power to enhance schooling in their country, instruments and means in accordance with their culturally embedded school system with its idiosyncrasy. How deeply effective these cultural understandings, institutions, and practices are has hardly been evaluated so far. This is astonishing, for the materializations of these cultures are just around the corner. One recent study (Overesch 2007) examined these cultures by comparing the Finnish and German educational policies using quantitative and qualitative methods. It found that despite the primacy of the Finnish system, it should not be copied by the Germans. Why not? The author says: "The most surprising result of the analysis is: Institutions in terms of historical experiences and cultural character are more important for the decision-making processes than institutions in terms of the decision rules" (Overesch 2007, p. 256). The naïve assumption of the planning ideology according to which there is, first, an existing problem that, second, has to be solved in a process is being reversed. The problems are results of the historically grown decision-making processes, and they, in turn, emerge from long-time cultural experiences (p. 257). Therefore the author traces the success of the Finnish system back to a cooperative and non-partisan culture in the Finnish society that allows a pragmatic educational policy. It is precisely this culture that is identified as the reason for the success in PISA, a culture that differs to a great degree from

\footnotetext{
12 The notion of "global model of school reform" does not refer to one single model implemented in every country in the world but to the ideological accordance between the global players such as the World Bank, the International Monetary Fund, or the UNESCO about how education should be organized. Countries less exposed to the need of financial aid by these players are of course more likely to defend their culturally idiosyncratic idea of schooling.
} 
the German culture. ${ }^{13}$ In other words, one can transfer formal structures but not cultural experiences that result in idiosyncratic attitudes predefining specific circumstances as problems and equally predefining the pertinent solutions to these problems. It is this historical cultural legacy that causes the phenomenon that the critics I mentioned in the introduction were describing - namely, that the global harmonization is limited to formal structures and does not get to the inner activities of education.

With this, I by no means advocate pessimism about the development of the schools neither do I reject large-scale assessments. My question is directed to the rather fundamental question of how research in education is characterized best in its traditional institutions of research, the university, in a time when non-university research institutions promote educational research oriented towards political and/or economical goals. Antecedent to the existence of these non-university research institutions educational research was excluded from all three, the millennial ambitions in the Cold War, its educational metamorphosis in the 1960s, and the turnaround to quality and output steering in the wake of the end of the Cold War in 1989. Now it has been invited to participate in the new governance culture, generating data according to the hardly legitimated standards and norms that pretend to be free of ideology and free of the specific cultures that students live in. However, this invitation to participate in the construction of "One World" is not solely a friendly act, for the agents of this new governance do not handle educational research with kid gloves. Obviously annoyed by the hesitation of research to become the helping hand of the new governance culture, OECD started to assess (paradoxically, with the help of international experts quite familiar with university research) the contributions of educational research in universities to policy makers in the different countries. In the case of Switzerland it was said: The "political and administrative entities are increasingly in need of scientific findings as a basis for decision-making; they also define research desiderata and commission specific research projects and studies. One question in this regard is whether the education sciences practised in Switzerland are capable of generating the governance knowledge required by policymakers and administrators while adequately addressing the issues that are of concern to educational practitioners." (OECD/CERI 2006, p. 5).

The same conflict occurred regarding economy and science in the early days of the OEEC (the predecessor of OECD) in 1948. Concerned with the enhancement of science for the sake of technological progress in order to implement the Marshall Plan in Europe and at the same time to fight communism, a scientific committee with tasks for both basic and applied research in economy and technology was being planned. However, at the first meeting the political stakeholders of the OEEC downgraded this committee to a "Working Party on Scientific and Technical Information." The frustration of the attendant scholars was enormous. As the then-member Alexander King reported in 2001, the Swedish colleague made a plea to live with this downgrade to supply information rather than to do research: "While we all regret that our task appears to have been narrowed to scientific information, does it really matter? After all, it is research, that generates information, and industry that applies it." In 1963, on the basis of the very same conflict, the Dutch Minister of Education accused the science policy of the OECD of fostering the "prostitution of science" (King 2001, pp. 340, 343). These conflicts stood at the outset of the dichotomy between expert-driven and primarily academic research altogether, and it seems that today

13 "The German Bundesländer have a totally different way of decision making in the fields of policy. Different values, experiences, interests, and styles of negotiation dominate the political class, which prevents fundamentally a consensual and pragmatic policy style" (Overesch 2007, p. 267 freely translated here). 
this conflict has reached the field of educational research: Expert-driven research tries to usurp academic research, whereas some exponents of the latter seem to be attracted by the alleged political power of the former.

Whatever this conflict will bring about, it becomes quite obvious that the OECD—based on a very meager educational theory of human capital - applies and contributes to a global system of communication about education in which numbers are performed with the pretension to cut off any subjectivity or particularity (Popkewitz 2009). By meeting these demands, however, academic research runs the risk of losing its academic legitimation: If research, namely, primarily contributes to this communication about education-sure enough in good faith to enhance school quality-it will foremost help to suggest a globally standardized reality that is representable by numbers. Suggesting this standardized reality, or the harmonized globe, however, automatically prevents research on the different idiosyncratic empirical realities, and the standardized empirical research setting ironically becomes un-empirical. But these realities do exist, and they are-as we have seen in even quite similar cultures such as Finland and Germany (both are Lutheran-dominated cultures) - characterized by cultural differences even in what is perceived to be a problem, let alone the solutions. If we become aware of the cultural significance of the homecoming queen in an American high school, or the role of ministrant in a Catholic context, or the fact that a coach of an American college football team can earn as much as 2 million dollars a year, then we start to realize that questions of quality are always related to broad cultural expectations about the child, the soul, the future citizen, social justice, and peace. These multiple realities are historical products that we need to retrace in order to understand them. This is the ultimate purpose of educational history-educational history not understood as the story of the past but rather as the story up to the present. This power of the silent actors in educational policy, the historically grown cultural expectations that affect—directly and indirectly_the constructions of education in their discursive and organizational appearances, have certainly not been considered enough. To do this in an international comparative way under omission of a de-contextualized and globalized tertium comparitionis is a project that against this background almost suggests itself. Where else than in small countries such as Luxembourg is one led to become involved in such a project?

\section{References}

Biesta, G. J. J. (2004). Education, accountability and the ethical demand. Can the democratic potential of accountability be regained? Educational Theory, 54(3), 233-250.

Chabbott, C. (2003). Constructing education for development. International organizations and education for all. New York: Routledge Falmer.

Conley, D. T. (2003). Who governs our schools? Changing roles and responsibilities. New York: Teacher's College Press.

Finn, Ch. E. (1991). Reinventing local control. Education Week, January 23, 32-40.

Fousek, J. (2000). To lead the world American nationalism \& the cultural roots of the Cold War. Chapel Hill, NC: The University of North Carolina Press.

Garmoran, A. (2007). School accountability, American style: Dilemmas of high-stakes testing. Schweizerische Zeitschrift für Bildungswissenschaften, 29, 79-94.

Gilman, N. (2003). Mandarins of the future modernization theory in Cold War America. Baltimore, MD: The Johns Hopkins University Press.

Hartwich, O. M. (2009). Neoliberalism: The genesis of a political swearword. CIS Occasional Paper 114, 21 May 2009. St. Leonards, Australia. www.cis.org.au/temp/op114_neoliberalism.pdf. Accessed 5 August 2009. 
King, A. (2001). Scientific concerns in an economic environment: Science in OEEC-OECD. Technology in Society, 23, 337-348.

Lerner, B. (1982). American education: How are we doing? The Public Interest, 69, 59-82.

Meyer, J. W., Boli, J., \& Thomas, G. M. (1994). Ontology and rationalization in the western cultural account. In W. R. Scott \& J. W. Meyer (Eds.), Institutional environments and organizations. Structural complexity and individualism (2nd ed., pp. 9-27). Thousand Oaks, CA: Sage.

Meyer, J. W., \& Ramirez, F. O. (2000). The world institutionalization of education. In J. Schriewer (Ed.), Discourse formation in comparative education (pp. 111-132). Frankfurt am Main: Peter Lang Publishing.

Meyer, J. W., \& Rowan, B. (1977). Institutionalized organizations: Formal structure as myth and ceremony. American Journal of Sociology, 83, 340-363.

Meyer, J. W., \& Rowan, B. (1978). The structure of educational organizations. In M. W. Meyer, et al. (Eds.), Environments and organizations (pp. 78-109). San Francisco, CA: Jossey-Bass.

National Commission on Excellence in Education. (1983). A nation at risk: The imperative for educational reform. Washington DC: US Department of Education.

Nye, D. E. (1994). The American technological sublime. Cambridge, MA: MIT Press.

OECD. (1961). Policy Conference on Economic Growth and Investment in Education. Washington 16th-20th October 1961. Paris: OECD Publishing.

OECD. (1979). Education policies in perspective: An appraisal. Paris: OECD Publishing.

OECD. (2001). Knowledge and skills for life. First results from PISA 2000. Paris: OECD Publishing.

OECD/CERI. (2006). OECD/CERI Review. Educational research and development in Switzerland country background report. Aarau: Swiss Coordination Center for Research in Education (SKBF).

Oelkers, J. (2004). Ziele der öffentlichen Bildung und die Entwicklung der Institution Schule. In St. Koch \& R. Fisch (Eds.), Schulen für die Zukunft. Neue Steuerung im Bildungswesen (pp. 33-50). Baltmannsweiler: Schneider Verlag Hohengehren.

Overesch, A. (2007). Wie die Schulpolitik ihre Probleme (nicht) löst. Deutschland und Finnland im Vergleich. Münster: Waxmann.

Popkewitz, T. (2009). Numbers in grids of intelligibility: Making sense of how educational truth is told. (Manuscript).

Schultz, T. W. (1962). Reflections on investment of man. The Journal of Political Economy, 70, 1-8.

Schultz, T. W. (1963). The economic value of education. New York: Columbia University Press.

Sufrin, S. C. (1963). Administering the National Defense Education Act. Syracuse, NY: Syracuse University Press.

Task Force on Education for Economic Growth. (1983). Action for excellence. A comprehensive plan to improve our nation's schools. Denver, CO: Education Commission of the States.

Tröhler, D. (2008). Verwaltung und Aufsicht der Zürcher Volksschule. In D. Tröhler \& U. Hardegger (Eds.), Zukunft bilden. Die Geschichte der Zürcher Volksschule (pp. 55-68). Zürich: Verlag Neue Zürcher Zeitung.

Truman, H. S. (1947). Special message to the congress on Greece and Turkey. http://www.presidency. ucsb.edu/ws/index.php?pid=12846. Accessed 5 August 2009.

Weisbrod, B. A. (1962). Education and investment in human capital. The Journal of Political Economy, 70, $106-123$.

Wirszup, I. (1981). The Soviet challenge. The new mathematics curriculum required of all students in the U.S.S.R. is superior of that of any other country. Educational Leadership, 38, 358-360. 